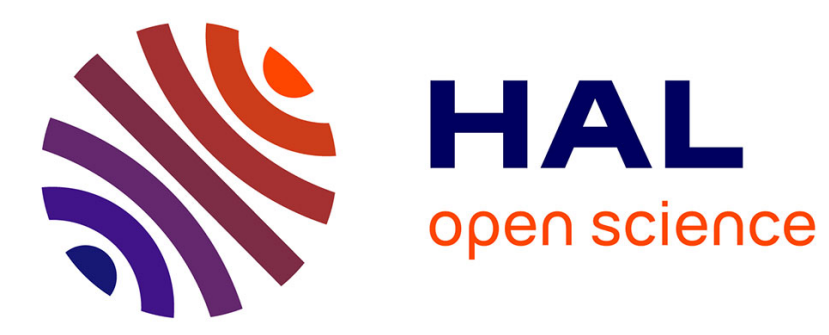

\title{
Frame effective tilt correction for HEM data acquired over rugged terrain
}

Pierre-Alexandre Reninger, Guillaume Martelet, José Perrin

\section{To cite this version:}

Pierre-Alexandre Reninger, Guillaume Martelet, José Perrin. Frame effective tilt correction for HEM data acquired over rugged terrain. First European Airborne Electromagnetics Conference Near Surface Geoscience 2015, EAGE, Sep 2015, Turin, Italy. hal-01170954

\section{HAL Id: hal-01170954 https://hal-brgm.archives-ouvertes.fr/hal-01170954}

Submitted on 2 Jul 2015

HAL is a multi-disciplinary open access archive for the deposit and dissemination of scientific research documents, whether they are published or not. The documents may come from teaching and research institutions in France or abroad, or from public or private research centers.
L'archive ouverte pluridisciplinaire $\mathbf{H A L}$, est destinée au dépôt et à la diffusion de documents scientifiques de niveau recherche, publiés ou non, émanant des établissements d'enseignement et de recherche français ou étrangers, des laboratoires publics ou privés. 


\section{Frame effective tilt correction for HEM data acquired over rugged terrain}

Reninger P.-A., Martelet G., Perrin J.

In a traditional HEM inversion scheme, the voltage data are usually normalized by the effective area of the system. This effective area depends on the tilt of the frame; the pitch and the roll of the frame are monitored during the survey with tilt-meters and used to calculate a correction term. However, using the measured tilt to calculate this term, it is assumed that the terrain is flat, which may lead to inaccuracies on the inversion results. Thus, though the correction term is generally small, it can prove important to accurately compute it in rugged terrain when high resolution is needed. The measured tilt has then to be corrected by the apparent slope of the ground in order to determine an effective tilt at each measurement location. In this work we compute the effective tilt and evaluate its contribution on inversion results. This was achieved on a recent survey conducted over La Réunion, which has a very rugged terrain. The inversion results obtained using the effective tilt were compared to the ones obtained with the measured tilt. Using the effective tilt in such environment has a clear effect in the inversion results, both on resistivity patterns and on the DOI. 